STUDIA PRAWNO-EKONOMICZNE, T. CVI, 2018

PLISSN 0081-6841; $\quad$ e-ISSN 2450-8179 $\quad$ s. 11-27

https://doi.org/10.26485/SPE/2018/106/1

\title{
Michał BŁOŃSKI*
}

\section{ODPOWIEDZIALNOŚĆ OSKARŻONEGO ZA POMÓWIENIE A PRAWO DO OBRONY}

\section{(Streszczenie)}

Artykuł dotyczy istotnych zagadnień teoretycznych i praktycznych wyjaśnień oskarżonego, których treść zawiera cechy pomówienia. W opracowaniu wskazano na rodzaje pomówień, ale przede wszystkim skoncentrowano się na tym, czy i kiedy oskarżony będzie ponosił odpowiedzialność karną za pomówienie innej osoby w ramach złożonych wyjaśnień. Zaakcentowano, że brak odpowiedzialności karnej oskarżonego za treść takich wyjaśnień ma miejsce wyłącznie wtedy, gdy oskarżony działa w celu obrony nie zaś ,pprzy okazji” obrony. Ustalenie, czy oskarżony będzie ponosić odpowiedzialność karną za treść pomówienia w zależności, czy działa w ramach prawa do obrony, czy przekracza te granice musi być zawsze rozpatrywane na tle realiów konkretnej sprawy. Prawo do obrony w analizowanym aspekcie, a zwłaszcza rozumienie pojęcia „w granicach prawa do obrony", powinno podlegać wykładni rozszerzającej, gdyż prawo to nie może być przez oskarżonego nadużywane.

Słowa kluczowe: przesłuchanie; dowód; prawo do obrony; wyjaśnienia oskarżonego; pomówienie

Szczególnym rodzajem wyjaśnień oskarżonego jest pomówienie. Pomówieniem jest zarzucanie innej osobie, że popełniła lub współuczestniczyła w popełnieniu przestępstwa czy przestępstwa skarbowego. Sam rodzaj takich wyjaśnień nie decyduje a'priori, czy ten środek dowodowy będzie przydatny dla poczynienia prawdziwych ustaleń faktycznych w sprawie. Z samego charakteru takich wyjaśnień nie wynika również, czy są one szczere, czy nieszczere. Podobnie jak i pozostały materiał dowodowy, wyjaśnienia oskarżonego przybierające postać pomówienia podlegają ocenie

\footnotetext{
* Dr, Uniwersytet Łódzki, Wydział Prawa i Administracji, Katedra Postępowania Karnego i Kryminalistyki, sędzia Sądu Okręgowego w Lodzi, wykładowca Krajowej Szkoły Sądownictwa i Prokuratury w Krakowie; e-mail: mblonski@wpia.uni.lodz.pl
} 
organu procesowego przez pryzmat art. 7 k.p.k. i jest to ocena dokonywana a'posteriori ${ }^{1}$.

W literaturze procesowej wyróżnić można kilka podziałów pomówie$n^{n} a^{2}$, a wśród nich pomówienie proste i złożone. To pierwsze polega na tym, że oskarżony przerzuca ciężar sprawstwa i winy na inną osobę. Chce $\mathrm{w}$ ten sposób uniknąć całkowicie odpowiedzialności karnej za zarzucane mu przestępstwo. Osobą, którą wskazuje w swoich wyjaśnieniach, jest najczęściej współoskarżony, ale może być to też osoba, która w ogóle nie występuje w danym procesie, choć jest sprecyzowana przez przesłuchiwanego albo też jej dane nie są bliżej skonkretyzowane. W pomówieniu złożonym oskarżony rozkłada ciężar sprawstwa $\mathrm{i}$ winy między siebie a inną lub inne osoby. Wskazując na udział $\mathrm{w}$ przestępstwie innej osoby, pomawiający $\mathrm{z}$ reguły umniejsza swoją rolę w przestępstwie, chcąc ograniczyć zakres swojej odpowiedzialności karnej. W ramach pomówienia złożonego można wyodrębnić pomówienie mogące mieć pozytywny wpływ na przyszły wymiar kary oraz takie, które takiego znaczenia nie ma lub może mieć znaczenie wręcz obciążające. Pomówienie, w którym oskarżony wskazuje na udział w zdarzeniu osób trzecich, jeżeli jednocześnie nie stawia się w ubocznej roli, co do zasady jest bardziej wiarygodne. Przykładem takich wyjaśnień jest stwierdzenie o udziale w przestępstwie innych osób przy jednoczesnym niekwestionowaniu wiodącej, a przynajmniej równorzędnej roli składającego takie wyjaśnienia. Działanie wspólnie i w porozumieniu stanowi okoliczność obciążającą i podanie takiej okoliczności może przemawiać za wiarygodnością i szczerością wyjaśnień. Szczególna skrupulatność i krytycyzm w ocenie tego dowodu będą wymagane, gdy oskarżony może zostać beneficjentem instytucji z art. $60 \S 3 \mathrm{k} . \mathrm{k}$. Wówczas bowiem, mimo wskazania na okoliczności z pozoru obciążające, mógłby on skorzystać z dobrodziejstwa nadzwyczajnego złagodzenia kary, a nawet warunkowego zawieszenia jej wykonania, jeżeli współdziałał w popełnieniu przestępstwa z innymi osobami. Pomówienie, które jawi się jako bezinteresowne, po wnikliwej analizie materiału dowodowego, ale i okoliczności pozaprocesowych, wcale takim być nie musi. Oskarżony może złożyć wyjaśnienia obciążające inną osobę nie tylko w celu uzyskania korzystniejszego dla siebie rozstrzygnięcia poprzez rozłożenie ciężaru odpowiedzialności za określone zachowanie, ale

T. Grzegorczyk, J. Tylman, Polskie postepowanie karne, Warszawa 2014, s. 485.

2 Por. A. Czapigo, Wyjaśnienia oskarżonego jako środek dowodowy w procesie karnym, WPP 2001/1, s. 74-75; J. Agacka, Wyjaśnienia oskarżonego - Pomówienie, AUL 1994/60, s. 120; B. Zając, Przyznanie się oskarżonego do winy w procesie karnym, Kraków 1995, s. 122. 
może tak uczynić na skutek zemsty czy dania swoistego rodzaju alibi pomawianemu, który w tym samym czasie i miejscu mógł popełnić inne poważniejsze przestępstwo.

Pomówienie może być prawdziwe lub fałszywe zarówno w całości, jak i w części. Aby pomówienie było fałszywe musi być fałszywe zarówno obiektywnie, jak i subiektywnie ${ }^{3}$. Fałszywość subiektywna (podmiotowa) oznacza, iż sprawca ma świadomość niezgodności z prawdą swojego oskarżenia (zarzutów). Fałszywość obiektywna (przedmiotowa) to niezgodność oskarżenia z obiektywnym stanem rzeczy, czyli stan, w którym oskarżenie jest wysuwane wobec osoby, która nie popełniła przestępstwa, które się jej zarzuca, lub popełniła je wprawdzie, lecz w oskarżeniu podaje się istotne, ale nieprawdziwe okoliczności ${ }^{4}$. Ocena wartości dowodowej pomówienia zawsze należy do organu procesowego, a w postępowaniu jurysdykcyjnym do sądu i dokonywana jest z uwzględnieniem całokształtu materiału dowodowego. Ocena ta musi być wnikliwa i krytyczna, albowiem informacje pochodzą od źródła dowodowego, które jest najbardziej zainteresowane w korzystnym dla siebie rozstrzygnięciu. Żaden inny podmiot, w tym np. biegły psycholog czy psychiatra, nie może zastąpić prokuratora czy sądu w analizie tego środka dowodowego i wnioskach po dokonaniu badań co do jego szczerości i wiarygodności ${ }^{5}$.

Z punktu widzenia intencji składającego wyjaśnienia co do prawdziwości podawanych faktów można wyodrębnić pomówienie szczere i nieszczere. Pomówienie szczere z reguły będzie w większym lub mniejszym stopniu odpowiadać rzeczywistości. Pomówienie nieszczere z zasady będzie kłamliwe. Kłamstwo jest działaniem zamierzonym, podejmowanym bez uprzedzenia odbiorcy, a osoba, która kłamie, wypowiada określony komunikat w przekonaniu, że jest to nieprawda ${ }^{6}$. Nie można oczywiście wykluczyć, że pomówienie nieszczere będzie odpowiadało rzeczywistości, co jednak nastąpi wbrew intencji wyjaśniającego i stanowić będzie nie tyle wyjątek, co wręcz przypadek.

3 M. Królikowski, R. Zawłocki (red.), Kodeks karny. Część szczególna. Tom II, Komentarz do art. 222-316, Warszawa 2013, Komentarz do art. 234 k.k., Legalis.

4 T. Razowski, w: J. Giezek (red.), Kodeks karny. Część szczególna. Komentarz, Warszawa 2014, s. 784; A. Grześkowiak, K. Wiak (red.), Kodeks karny. Komentarz, Warszawa 2017, wyd. 4, Komentarz do art. 234 k.k., Legalis.

5 M. Błoński, w: P. Kruszyński, M. Błoński, M. Zbrojewska, Dowody i postępowanie dowodowe w procesie karnym. Komentarz praktyczny z orzecznictwem. Wzory pism procesowych, Warszawa 2015, s. 140; E. Gruza, Psychologia sądowa dla prawników, Warszawa 2017, s. 315; M. Leśniak, Wybrane problemy badań psychologicznych w procesie karnym, Prokuratura i Prawo 1998/5, s. 69; postanowienie SN z 5 maja 2006 r., V KK 387/05, LEX nr 186970.

6 B.W. Wojciechowski, Analiza i ocena zeznań świadków, Sopot 2016, s. 38. 
Można wyróżnić pomówienie konsekwentne, którego przeciwieństwem jest pomówienie odwołalne. Każde z nich może być dowodem w sprawie, a odwołanie pomówienia, podobnie jak i innych wyjaśnień, nie eliminuje ich z procesu i nie przesądza oceny w zakresie ich wiarygodności ${ }^{7}$. Zasadniczo oskarżeni mają większą skłonność do szczerości w toku pierwszego przesłuchania, a następnie wycofywania się z zajętego stanowiska, dlatego oparcie ustaleń na podstawie pomówienia, choć cofniętego, nierzadko zasługuje na akceptację. Badając wiarygodność pomówienia, które zostało cofnięte, należy również skrupulatnie baczyć na powody, na które powołuje się oskarżony, uzasadniając odwołanie pomówienia, i na ich podstawie ustalić, czy i ewentualnie które z wyjaśnień stanowią wiarygodny środek dowodowy ${ }^{8}$.

Pomówienie może pozostawać w bezpośrednim związku z zarzutami postawionymi podejrzanemu, a następnie oskarżonemu, czyli w swej treści nawiązywać do czynów będących przedmiotem postępowania. W opozycji do tego rodzaju pomówienia jest obciążanie innej osoby popełnieniem przestępstwa, niezależnie od ewentualnych też form stadialnych i zjawiskowych, bez związku z zarzutami oskarżenia. Wskazanie granic między tymi dwiema formami pomówienia ma istotne znaczenie praktyczne, gdyż wyznacza zakres ewentualnej odpowiedzialności karnej pomawiającego w kontekście jego prawa do obrony. Prawo to ma rangę konstytucyjną, wynikającą z art. 42 ust. 2 Konstytucji RP. Stanowi ono fundamentalną gwarancję procesową, będąc zarazem podstawowym podmiotowym prawem człowieka.

Jeszcze pod rządami k.p.k. z 1928 r. Sąd Najwyższy wyraził stanowisko, iż wyjaśnienia złożone przed władzą lub urzędem, powołanymi do ścigania przestępstw, i świadome fałszywe oskarżenie innej osoby o popełnienie czynu zarzucanego oskarżonemu lub innego przestępstwa albo współdziałania w nim stanowi przekroczenie prawa do obrony i jest występkiem z art. 143 k.k. z 1928 r. (dziś - art. 234 k.k.)9. Analiza samej tylko tezy uchwały Sądu Najwyższego nie pozwala na zajęcie stanowiska co do jej słuszności z uwagi na zbytnią ogólnikowość. Aprobując generalnie wskazany pogląd, w doktrynie

Por. S. Śliwiński, Polski proces karny przed sądem powszechnym. Zasady ogólne, Warszawa 1948, s. 635.

8 Por. np. wyrok SN z 15 lutego 1985 r., IV KR 25/85, OSNKW 1985/11-12, poz. 103; wyrok SN z 9 kwietnia 1974 r., III KR 32/74, Biul. SN 1974/9-10, poz. 228; wyrok SN z 11 września 1984 r., IV KR 141/84, OSNPG 1985/6, poz. 85.

9 Uchwała SN z 18 lutego 1961 r., VI KO 29/59, OSPiKA 1961/7-8, s. 462-464. 
wskazywano $^{10}$, że oskarżony nie może swoimi kłamliwymi wyjaśnieniami godzić $\mathrm{w}$ dobra chronione prawem i nie ponosić $\mathrm{z}$ tego tytułu żadnych ujemnych następstw w sferze prawa karnego. Granice prawa do obrony mają ograniczony zakres i nie powinny wykraczać poza sferę, w której dochodzi do poświęcenia innych istotnych dóbr kosztem prawa do obrony. Oskarżony, zarzucając popełnienie przestępstwa innej osobie, nie działa w warunkach obrony koniecznej, gdyż nie odpiera bezpośredniego, bezprawnego zamachu (art. $25 \S 1$ k.k.). Nie działa on też w warunkach stanu wyższej konieczności, ponieważ oskarżenie oparte na przesłankach faktycznych i prawnych stanowi wykonywanie prawa, a działanie w celu uniknięcia odpowiedzialności karnej za popełnione przestępstwo nie jest działaniem prawnie chronionym (art. $26 \S 1$ k.k.). W związku z powyższym oskarżony w razie pomówienia innej osoby o popełnienie przestępstwa powinien ponosić odpowiedzialność karną z dzisiejszego art. 234 k.k.

R. Łyczywek wyraził z kolei pogląd, że karalność oskarżonego za fałszywe pomówienie nie budzi wątpliwości, zwłaszcza jeśli występuje u niego większe natężenie złej woli w trakcie składanych fałszywych wyjaśnien ${ }^{11}$. Część przedstawicieli doktryny opowiedziało się za tym rozwiązaniem, dodatkowo wskazując, że oskarżony zawsze powinien odpowiadać z art. 234 k.k. (z art. 143 k.k. z 1932 r.), choćby dokonywał tego dla swej obrony, jeżeli świadomie fałszywie oskarża inne osoby ${ }^{12}$. Ochroną objęty jest też współoskarżony, jeżeli wyjaśnienia innego oskarżonego miałyby doprowadzić do niekorzystnego rozstrzygnięcia osoby de facto niewinnej, choć postawionej w stan oskarżenia ${ }^{13}$. Zapatrywania te, może i częściowo słuszne z dogmatycznego punktu widzenia, są jednak niemożliwe do wykorzystania w praktyce. Nie istnieją bowiem instrumenty pozwalające na badanie stopnia natężenia złej woli oskarżonego w trakcie składanych wyjaśnień, a od tego zdaje się miałaby zależeć odpowiedzialność oskarżonego za fałszywe pomówienie. Trudności wywoływałoby też ustalenie, kiedy mamy do czynienia $\mathrm{z}$,większym" natężeniem tej złej woli i w stosunku do czego oraz gdzie przebiega granica, przekroczenie której uzasadniałoby

10 J. Bratoszewski, L. Gardocki, Z. Gostyński, S.M. Przyjemski, R.A. Stefański, S. Zabłocki, Kodeks postepowania karnego. Komentarz, t. I, Warszawa 1998, s. 778; W. Daszkiewicz, Samooskarżenie a prawo do milczenia, PiP 1974/2, s. 10-11; Z. Papierkowski, Granice obrony oskarżonego w procesie karnym, Głos Prawa 1935/9 -10, s. 545 i n.; A. Dąb, Prawo do obrony, PiP 1954/3, s. 444.

11 R. Lyczywek, Prawo oskarżonego do wypowiadania się w procesie, PiP 1970/2, s. 303-304.

12 M. Lipczyńska, Stanowisko oskarżonego w procesie karnym Polski Ludowej, Warszawa 1956, s. 168; por. także: K.J. Pawelec, Wyjaśnienia podejrzanego, zeznania świadka i instytucja świadka koronnego. Komentarz, Warszawa 2003, s. 33.

13 Postanowienie SN z 25 kwietnia 1995 r., II KO 6/95, Prokuratura i Prawo 1995/7-8, poz. 7. 
pociągnięcie oskarżonego do odpowiedzialności karnej za treść jego wyjaśnień. Z kolei opowiedzenie się za karalnością oskarżonego, gdy ma on świadomość fałszywego oskarżenia, stanowi aprobatę dla sygnalizowanej uchwały Sądu Najwyższego. Według tego poglądu w istocie każde fałszywe oskarżenie innej osoby winno rodzić odpowiedzialność karną z art. 234 k.k., przy czym przez fałszywość oskarżenia należałoby rozumieć zarówno fałszywość subiektywną, jak i obiektywną.

Wydaje się, że należy opowiedzieć się za trzecim rozwiązaniem, które w sposób bardziej kompleksowy odnosi się do zagadnienia pomówienia w postaci fałszywego oskarżenia innej osoby o popełnienie przestępstwa i relacji takich wyjaśnień do prawa do obrony. Prawo do obrony w polskim porządku prawnym ma rangę konstytucyjną i jest zagwarantowane w art. 42 ust. 2 Konstytucji $\mathrm{RP}^{14}$, a także znajduje umocowanie tak w aktach prawa międzynarodowego, tj. w art. 6 pkt 3 Konwencji o Ochronie Praw Człowieka i Podstawowych Wolności ${ }^{15}$, jak i w art. 6 k.p.k. O tym, czy oskarżony będzie ponosił odpowiedzialność karną za treść pomawiających wyjaśnień, decyduje to, czy przerzucając ciężar odpowiedzialności w całości lub w części na inną osobę, działa w ramach prawa do obrony, czy też tylko „przy okazji” obrony, wykorzystując tym samym swój status procesowy, aby skierować oskarżenie na inną osobę. Jeżeli oskarżony pomawia inną osobę o czyn jemu zarzucany, działając w celu obrony, czyli uwolnienia lub ograniczenia zakresu swojej odpowiedzialności karnej, to działa $\mathrm{w}$ ramach przysługującego prawa do obrony i w konsekwencji nie ponosi odpowiedzialności karnej z art. 234 k.k. ${ }^{16} \mathrm{Wy}-$ łączenie odpowiedzialności ze wskazanego przepisu zaistnieje, gdy oskarżony w wyjaśnieniach wskazywać będzie na sprawstwo innej osoby za zarzucany jemu czyn lub też powoływać się będzie na różne formy współsprawstwa, w tym popełnienie czynu w formach zjawiskowych, które miałyby wskazywać

14 Konstytucja Rzeczypospolitej Polskiej z dnia 2 kwietnia 1997 r. (Dz.U., nr 78, poz. 483 ze zm.).

15 Konwencja z dnia 4 listopada 1950 r. o Ochronie Praw Człowieka i Podstawowych Wolności (Dz.U. z 1993 r., nr 61, poz. 284).

16 Por. T. Gardocka, Materialne granice prawa do obrony $w$ procesie karnym, w: Prawo do obrony w postepowaniu penalnym, Warszawa 2014, s. 34; B. Kunicka-Michalska, Prawo oskarżonego do obrony, a fatszywe oskarżenie, Palestra 1968/6, s. 44-46; J. Agacka, Wyjaśnienia oskarżonego..., s. 124-126; Z. Sobolewski, Samooskarżenie w świetle prawa karnego, Warszawa 1982, s. 92 i n.; J. Nelken, Wyjaśnienia oskarżonego na tle kodeksu postępowania karnego, Palestra 1971/5, s. 77; M. Szewczyk, w: Kodeks karny. Część szczególna, t. II, A. Zoll (red.), Warszawa 2013, s. 1246-1249; T. Grzegorczyk, J. Tylman, Polskie..., s. 485; wyrok SN z 15 września 1970 r., V KRN 311/70, NP 1971/3, s. 404. 
na jego podrzędną rolę w zdarzeniu, albo też na wiodącą czy determinującą jego zachowanie postawę innych osób. Ten ostatni przypadek zaistnieje wtedy, gdy np. oskarżony przyznaje się wprawdzie do zarzucanego czynu, choć twierdzi, niezgodnie z prawdą, że został sprowokowany do określonego zachowania przez pokrzywdzonego. Oskarżony działa wówczas w ramach prawa do obrony, a jego wyjaśnienia, w części nieszczere i nieprawdziwe, mają na celu łagodniejsze potraktowanie $\mathrm{w}$ ramach stosowania dyrektyw wymiaru kary i środków karnych ${ }^{17}$.

Opisane działanie to swoistego rodzaju quasi-kontratyp wyłączający możliwość pociągnięcia sprawcy do odpowiedzialności karnej za przestępstwo fałszywego pomówienia. Kontratyp jest typem zachowania składającego się z dwóch elementów: zespołu znamion typu czynu zabronionego i zespołu znamion okoliczności wyłączającej bezprawność. Warunkiem wystąpienia kontratypu jest zrealizowanie znamion czynu zabronionego ${ }^{18}$. W ramach realizacji prawa do obrony nie jest to kontratyp jako okoliczność wyłączająca bezprawność, ale inna okoliczność o podobnym charakterze w postaci działania $\mathrm{w}$ granicach uprawnień nadanych danemu podmiotowi, którym jest oskarżony, oraz przysługującego mu prawa do obrony i w jej granicach. Oskarżony, działając $\mathrm{w}$ granicach przysługującego mu prawa, nie realizuje znamion czynu zabronionego, dlatego nie jest to kontratyp, który wyłącza bezprawność zachowania sprawcy. Przyjęcie odmiennego stanowiska oznaczałoby istotne ograniczenie tego prawa. Oskarżony mógłby stawać przed dylematem, czy aktywnie się bronić, ale i ryzykować odpowiedzialność karną z art. 234 k.k. na wypadek niepotwierdzenia tez przez niego wysuwanych, czy skorzystać z formy obrony biernej i np. odmówić składania wyjaśnień. Ściganie sprawców takich czynów (z art. 234 k.k.) nie byłoby też racjonalne z punktu widzenia polityki kryminalnej, a wręcz mogłoby sprowadzać się do kreowania sztucznej przestępczości. Oskarżeni zdeterminowani w realizacji prawa do obrony ponosiliby ryzyko odpowiedzialności za przestępstwo z art. 234 k.k. i tym samym kolejnego procesu czy postawienia nowego zarzutu, którego społeczna szkodliwość mogłaby być nawet oceniana w granicach znikomości w kontekście realnej walki o korzystne rozstrzygnięcie i odpierania zarzutów o popełnienie dużo poważniejszych przestępstw. Mogłoby to powodować również

17 Por. M. Klejnowska, Oskarżony jako osobowe źródło informacji o przestęstwie, Kraków 2004, s. 258.

18 A. Zoll, w: Kodeks karny. Część ogólna, W. Wróbel, A. Zoll (red.), Warszawa 2016, s. 536-537;

A. Zoll, Okoliczności wyłączające bezprawność czynu. Zagadnienia ogólne, Warszawa 1982, s. 128. 
przedłużanie procesów i podejmowanie czynności dowodowych w kwestiach ubocznych zamiast koncentrować się na rozwiązywaniu zasadniczego przedmiotu procesu w danej sprawie. Ponadto w sprawach, w których $\mathrm{w}$ grę wchodzą znaczne emocje, niekoniecznie zresztą proporcjonalne do wagi czynów, zwłaszcza o czyny ścigane z oskarżenia prywatnego, oskarżony, broniąc się przed zarzutem i starając się przerzucić ciężar odpowiedzialności na swojego adwersarza czy choćby zarzucając mu zachowania prowokacyjne, mógłby stanąć pod drugim zarzutem, tym razem ściganym z oskarżenia publicznego, czyli o czyn z art. 234 k.k. Należy też zaznaczyć, że grożąca oskarżonemu odpowiedzialność za przestępstwo z art. 234 k.k. mogłaby nie sprzyjać woli ujawniania rzeczywistych współsprawców zarzucanego czynu, co nie pozostaje bez wpływu na interes wymiaru sprawiedliwości.

Reasumując, należy stwierdzić, że oskarżony, pomawiając inną osobę o popełnienie przestępstwa, które się jemu zarzuca, nie popełnia przestępstwa z art. 234 k.k., gdyż w przeciwnym razie stanowiłoby to ograniczenie konstytucyjnego prawa do obrony. Nadto, skoro nie odpowiada on za fałszywe oświadczenia czy wyjaśnienia, to nie może odpowiadać za fałszywe oskarżenie lub inne przestępstwa z tych bezkarnych i fałszywych wyjaśnień wynikające ${ }^{19}$.

Ustalenie, czy oskarżony będzie ponosić odpowiedzialność karną za treść pomówienia w zależności, czy działa w ramach prawa do obrony, czy przekracza te granice, nie jest zadaniem łatwym i musi być każdorazowo rozpatrywane na tle realiów konkretnych stanów faktycznych. Nie wydaje się jednak, że prawo do obrony w analizowanym aspekcie, a zwłaszcza wykładania pojęcia „W granicach prawa do obrony”, powinno podlegać wykładni rozszerzającej. Prawo to nie może być przez oskarżonego nadużywane.

Nie nastręcza większych problemów sytuacja, gdy oskarżony w swych wyjaśnieniach oskarża inne osoby o popełnienie przestępstwa, jeśli nie pozostaje to w związku z czynem bezpośrednio jemu zarzucanym. Dzieje się to wtedy, kiedy oskarżony, wykorzystując fakt, iż jest przesłuchiwany przed organami ścigania lub przed sądem, fałszywie oskarża określoną osobę o określone czyny. Nie może on liczyć na bezkarność, gdyż czyni to „przy okazji prawa do obrony” we własnej sprawie. $\mathrm{O}$ ile w razie istnienia kolizji dóbr między prawem do obrony a ochroną innej osoby przed oskarżeniem to pierwsze dobro ma co do zasady prymat, o tyle w opisanym przypadku brak jest jakiejkolwiek rzeczywistej kolizji dóbr. Oskarżony pomawiający inne osoby o popełnienie przestępstw wykracza poza granice prawa obrony, działa w ramach ekscesu obrony, na „własne

19 M. Cieślak, Glosa do uchwaty SN (7) z 29 VI 1972 r., VI KZP 67/71, PiP 1973/11. 
ryzyko", które może spowodować wszczęcie odrębnego postępowania karnego, gdzie ponownie w roli oskarżonego wystąpi ta sama osoba ${ }^{20}$.

Wąskie rozumienie prawa do obrony i brak odpowiedzialności karnej za fałszywe pomówienie wiąże się z działaniem służącym realizacji prawa do obrony tylko konkretnego oskarżonego. Chodzi jedynie o własną obronę oskarżonego przed zarzucanym mu przestępstwem lub walkę procesową z materiałem dowodowym jego obciążającym. Sąd Najwyższy stanął na stanowisku, iż oskarżony, który składając wyjaśnienia w związku z toczącym się przeciwko niemu postępowaniem karnym, fałszywie pomawia inną osobę o współudział w tym przestępstwie w celu ukrycia tożsamości rzeczywistych współuczestników tego przestępstwa, a nie w celu własnej obrony, wykracza poza granice przysługującego mu prawa do obrony i może ponosić odpowiedzialność karną z art. 234 k.k. ${ }^{21}$ Zasadniczo ten judykat najwyższej instancji zasługuje na aprobatę. Wyłączenie odpowiedzialności za przestępstwo z art. 234 k.k. ma służyć przecież ochronie i realizacji prawa do obrony tego oskarżonego, który składa wyjaśnienia określonej treści, nie zaś potencjalnych współsprawców, których w ogóle udział i rola w zdarzeniu przestępczym nie została ustalona, a nawet jeśli została ustalona, to nie występują oni $\mathrm{w}$ in concreto toczącym się procesie. Rudymentarne znaczenie ma jednak to, czy oskarżony, składając wyjaśnienia o charakterze pomawiającym, działa w celu ukrycia tożsamości rzeczywistych sprawców, czy w ramach swojego prawa do obrony lub też, czy te cele są współrealizowane jednocześnie. Odpowiedź na to pytanie powinna zapaść po wszczęciu postępowania przygotowawczego o czyn z art. 234 k.k. lub też na przedpolu tego postępowania, czyli w ramach czynności sprawdzających, kiedy oskarżyciel publiczny będzie musiał podjąć decyzję, czy w ogóle wszcząć postępowanie w sprawie o przestępstwo z art. 234 k.k. Poczynienie jednoznacznych ustaleń może być niezwykle trudne, a niekiedy wręcz awykonalne. Oskarżony może składać pomawiające wyjaśnienia, obarczając odpowiedzialnością inne osoby, jeżeli oczywiste jest, że czyn został popełniony w strukturze wieloosobowej, natomiast organ procesowy nie posiada informacji co do danych współsprawców. Postawa oskarżonego może być determinowana nie tyle wolą ochrony rzeczywistych sprawców, lecz tym, aby ci, w razie ich ujawnienia i pociągnięcia do odpowiedzialności karnej, nie złożyli obciążających go wyjaśnień. Bezspornie jednak taka postawa oskarżonego chroni jednocześnie

20 A. Marek, Kodeks karny. Komentarz, Warszawa, 2005, s. 511.

${ }^{21}$ Por. uchwała SN z 11 stycznia 2006 r., I KZP 49/05, OSNKW 2006/2, poz. 12; P. Wiliński, Glosa do uchwaty SN z 11 stycznia 2006 r., I KZP 49/05, OSP 2007/5; M. Kucharczyk, Glosa do uchwaty SN z 11 stycznia 2006 r., I KZP 49/05, Monitor Prawniczy 2007/14. 
współsprawców, co jednak nie uzasadnia pociągnięcia do odpowiedzialności z art. 234 k.k. Oskarżony realizuje tu jednak swoje prawo do obrony, zaś tylko obok niego chroni rzeczywistych współsprawców przestępstwa. Ta ochrona występuje niejako na uboczu prawa, do obrony, jest następstwem tego prawa, choć pozostaje $\mathrm{z}$ nim $\mathrm{w}$ istotnym związku. Zasadnym wydaje się pociągnięcie oskarżonego do odpowiedzialności karnej w związku z przekroczeniem granic prawa do obrony, jeżeli jedynym i niebudzącym wątpliwości celem jego wyjaśnień jest ochrona współsprawców. Każdorazowe ustalenie granic prawa do obrony w przypadku podejrzenia ich przekroczenia poprzez pomówienie innej osoby winno być rozważane na tle realiów danej sprawy, ponieważ nie istnieją obiektywne możliwości wypracowania teoretycznych i w pełni wystarczających kryteriów oceny zdarzeń, pozwalających na jednoznaczne wnioski, dotyczące tego, kiedy oskarżony, składając fałszywe i pomawiające inną osobę wyjaśnienia, działał w granicach prawa do obrony, a kiedy je przekroczył.

Podsumowując powyższe, należy dojść do konstatacji, iż w przypadku rozważania odpowiedzialności oskarżonego z art. 234 k.k. za treść pomawiających wyjaśnień każdorazowo należy ustalić cel ich składania. Jeżeli będzie nim uniknięcie odpowiedzialności za zarzucany czyn, złagodzenie tej odpowiedzialności, podważenie wiarygodności dowodu obciążającego lub wyeliminowanie określonego dowodu z materiału dowodowego, to oskarżony nie będzie ponosił odpowiedzialności karnej za treść pomówienia. A contrario, gdy jego wyjaśnienia o charakterze pomawiającym nie mają żadnego związku z zarzuconym mu czynem lub obroną przed nim, ale i wówczas, kiedy fałszywe oskarżenie wprawdzie pozostaje w związku z tym czynem, lecz oskarżony złożył je nie dla obrony przed zarzucanym czynem, ale wyłącznie w innym celu, to takie zachowanie może być przedmiotem analizy z punktu widzenia odpowiedzialności karnej za treść złożonych wyjaśnieńn ${ }^{22}$.

Poprzez pomówienie oskarżony może też realizować znamiona rodzajowe przestępstwa $\mathrm{z}$ art. $212 \S 1$ k.k. Jeżeli zarzut podniesiony przez oskarżonego nie zmierza wyłącznie do poniżenia innej osoby, ale ma charakter działania obrończego, to nie stanowi on zniesławienia ${ }^{23}$.

Odmienne stanowisko zajął pod rządem k.p.k. z 1969 r. Sąd Najwyższy, wskazując, że złożone przed sądem wyjaśnienia oskarżonego stawiające nieprawdziwy zarzut stosowania wobec niego przez funkcjonariusza MO

22 Por. wyrok SN z 22 października 2013 r., V KK 233/13, OSNKW 2014/3, poz. 21; wyrok SA w Lublinie z 16 stycznia 2014 r., II AKa 261/13, KZS 2014/5, poz. 75.

23 Wyrok SN z 15 września 1970 r., V KRN 311/70, NP 1971/3, s. 404. 
niedozwolonych metod śledczych, mogą stanowić przestępstwo z art. 178 $\S 1$ k.k. (z 1969 r.; dziś - art. 212 § 1 k.k.), gdy sprawca działa w celu poniżenia tego funkcjonariusza $\mathrm{w}$ opinii publicznej lub narażenia go na utratę zaufania potrzebnego do pełnienia funkcji ${ }^{24}$. Aktualnie stanowisko to nie jest podzielane $\mathrm{w}$ doktrynie ${ }^{25}$. Bezspornie działania oskarżonego w kierunku zdyskredytowania materiału dowodowego i powoływanie się na niedozwolone metody przesłuchania (art. $171 \S 6$ k.p.k.) mieszczą się w ramach wykonywania prawa do obrony procesowej przez oskarżonego. Jeżeli podniesione zarzuty okazałyby się słuszne, wówczas wyjaśnienia oskarżonego nie stanowiłyby dowodu w sprawie (art. $171 \S 7$ k.p.k.). Uprawdopodobnienie wysuwanego zarzutu o stosowaniu niedozwolonych metod przesłuchania należy do oskarżonego (podejrzanego). Uwzględniając kameralne warunki przesłuchania na etapie dochodzenia lub śledztwa, z reguły odbywającego się w niewielkich pomieszczeniach, w obecności tylko przesłuchującego i przesłuchiwanego, nie jest to zadaniem łatwym. Ewentualna odpowiedzialność oskarżonego z art. $212 \S 1$ k.k. i obawa przed nią mogłyby dodatkowo wpływać hamująco na zmianę wyjaśnień poprzez odwołanie uprzednio już złożonych z powołaniem się na to, że zostały one uzyskane w warunkach wyłączających swobodę wypowiedzi.

Konstytucyjne prawo do obrony oskarżonego, które pozwala mu na swobodę wypowiedzi w zakresie zarzucanego czynu i które chroni go przed poniesieniem odpowiedzialności karnej z powodu ich treści, nie legalizuje jednak innych zachowań oskarżonego o znamionach czynu zabronionego, choćby zmierzały do uniknięcia bądź złagodzenia odpowiedzialności za czyn zarzucony ${ }^{26}$. Nie podlega ochronie niszczenie dowodów, namawianie świadków do składania fałszywych zeznań czy bezprawne wpływanie na przedstawicieli wymiaru sprawiedliwości pod kątem interesu procesowego oskarżonego, np. w celu opóźnienia zakończenia procesu.

Kontrowersje może budzić ocena zachowania oskarżonego na rozprawie, który w ramach składanych wyjaśnień lub wniosków formalnych oskarża sędziów o zachowania, które wyczerpują znamiona przestępstwa, np. łapownictwa, i żąda ich wyłączenia od rozpoznania sprawy. Dalszą konsekwencją

Uchwała SN (7) z 29 czerwca 1972 r., VI KZP 67/71, OSNKW 1972/10, poz. 150.

25 Por. T. Grzegorczyk, J. Tylman, Polskie..., s. 333; M. Cieślak, Glosa do uchwaty SN (7) z 29 czerwca 1972 r., VI KZP 67/71, PiP 1973/11, s. 183; B. Zając, Przyznanie sie ..., s. 125-126; J. Nelken, Glosa uchwaty SN (7) z 29 czerwca 1972 r., VI KZP 67/71, NP 1973/7-8, s. 1198;

P. Kruszyński, Realizacja prawa do obrony na rozprawie głównej, Studia Iuridica 1985/13, s. 102-103.

26 Wyrok SN z 9 lutego 2004 r., V KK 194/03, OSNKW 2004/4, poz. 42. 
takiej postawy procesowej oskarżonego może być złożenie do sądu cywilnego pozwu przeciwko sędziemu o zwrot uzyskanej rzekomo korzyści majątkowej od oskarżonego, a nadto może on jeszcze złożyć zawiadomienie o przestępstwie mającym być popełnionym przez sędziego. Jednocześnie z analizy zachowania oskarżonego $\mathrm{w}$ toku procesu i określonych uwarunkowań znajdujących odzwierciedlenie w aktach sprawy może wynikać, że rzeczywistym celem takich działań jest sparaliżowanie procesu poprzez wyłączenie sędziego od rozpoznania sprawy, co miałoby skutkować prowadzeniem rozprawy od początku.

Uwzględniając wskazane powyżej okoliczności, można opowiedzieć się za uznaniem działań oskarżonego jako realizujących jego uprawnienia procesowe, gdyż korzysta on $\mathrm{z}$ instytucji, które są przewidziane w obowiązujących przepisach. Oskarżony dąży do określonego celu, jakim jest przedłużenie czasu trwania postępowania, licząc np., że wkrótce nastąpi uchylenie stosowanego tymczasowego aresztowania, a zakończenie postępowania wyrokiem zrodzi dla niego niebezpieczeństwo dalszego stosowania izolacyjnego środka zapobiegawczego w oparciu o art. $258 \S 2$ k.p.k. do czasu rozpoczęcia wykonywania orzeczonej kary pozbawienia wolności.

Dogłębna analiza sposobu reakcji oskarżonego na bieg procesu musi jednak prowadzić do konstatacji, że oskarżony w opisywanej sytuacji jawnie wykracza poza zakres przysługujących mu uprawnień procesowych, a zwłaszcza poza granice prawa do obrony. Nie wszystkie działania, które mogą przynieść dla oskarżonego pożądany przez niego rezultat procesowy, są dozwolone i mieszczą się w granicach prawa do obrony. Realizacja przez oskarżonego prawa do obrony nie może prowadzić do ewidentnych jego nadużyć, gdyż wówczas zachowanie takie nie jest już prawnie dozwolone, staje się bezprawne, a wręcz stanowi przejaw wynaturzenia prawa do obrony. O ile oskarżony ma prawo składać wnioski o wyłączenie sędziego, o tyle nie zawsze zaprezentowane przesłanki mające to uzasadniać będą prawnie irrelewantne z punktu widzenia skutków, jakie mogą wywołać w sferze prawa karnego materialnego dla samego wnioskodawcy. Oskarżony, który składa wniosek o wyłączenie sędziego, a następnie zawiadomienie o popełnieniu przez niego przestępstwa łapownictwa, wiedząc, że przestępstwa nie popełniono, podlega odpowiedzialności karnej z art. 234 k.k., gdyż ten ostatni przepis pochłonie czyn z art. 238 k.k. ${ }^{27}$ Samo złożenie wniosku

27 Wyrok SN z 14 września 2004 r., IV KK 129/04, LEX nr 137755; T. Razowski, w: J. Giezek (red.), Kodeks..., s. 804; B. Kunicka-Michalska, w: Kodeks karny. Część szczególna. Komentarz, t. II, A. Wąsek (red.), Warszawa 2004, s. 189; odmiennie: R.A. Stefański, Zawiadomienie o niepopetnionym przestępstwie w świetle prawa karnego, Prokuratura i Prawo 2005/10, s. 42; J. Wojciechowski, Kodeks karny. Komentarz. Orzecznictwo, Warszawa 1998, s. 425. 
o wyłączenie sędziego, jako uprawnienie procesowe, nie może eo ipso legitymizować treści zawartych we wniosku, na które powołuje się wnioskodawca.

Jeżeli oskarżony nie składa zawiadomienia o popełnieniu przestępstwa, lecz zarzuca we wniosku sędziemu popełnienie przestępstwa, ponosi odpowiedzialność karną z art. $212 \S 1$ k.k. Tym bardziej uzasadnione jest skierowanie ścigania przeciwko takiemu oskarżonemu, który składa powództwo cywilne przed sądem cywilnym, domagając się zwrotu rzekomo udzielonej sędziemu korzyści majątkowej. We wskazanym przypadku działanie oskarżonego, mimo że nakierowane jest na wykreowanie pozorów sporu między nim a rozpoznającym jego sprawę sędzią, co miałoby uzasadniać wyłączenie sędziego od rozpoznania sprawy karnej, nie może zasługiwać na aprobatę aparatu wymiaru sprawiedliwości. Oprócz oczywistej bezzasadności wniosku o wyłączenie sędziego wskutek wskazanych działań, których ewentualna akceptacja mogłaby sparaliżować każdy proces, oskarżony powinien ponieść konsekwencje swojego zachowania, które wykracza poza ramy prawa do obrony. Należy dodać, że opisywane postępowanie jest tylko z pozoru podobne do działań oskarżonego, który zarzuca organom ścigania wpływanie na swobodę wypowiedzi poprzez np. stosowanie środków przymusu w toku przesłuchania w postępowaniu przygotowawczym. Oskarżony nie powołuje się w tym przypadku na wyłączenie swobody wypowiedzi, co mogłoby skutecznie zmierzać do unicestwienia jego wyjaśnień jako dowodu w sprawie, lecz zarzuca innemu uczestnikowi postępowania działania przestępcze, które mogłyby wyłącznie pośrednio wpływać na jego sytuację procesową i to tylko pod warunkiem, że zarzuty te byłyby prawdziwe. Ponadto wpływ na tę sytuację nie dotyczyłby odpowiedzialności za zarzucany oskarżonemu czyn, lecz co najwyżej rzutowałby na wydłużenie czasu trwania toczącego się procesu poprzez zmianę składu orzekającego. Oskarżony jednak zdaje sobie sprawę z tego, że zarzuty są kłamliwe, godzą w dobra prawnie chronione innej osoby i nie pozostają w żadnym związku z zarzutem oskarżenia, dlatego nie mogą zasługiwać na ochronę prawną. W razie zaistnienia takiej sytuacji prokurator z urzędu (art. $60 \S 1$ k.p.k.) powinien wszcząć postępowanie o czyn prywatnoskargowy z art. $212 \S 1$ k.p.k., gdyż wymaga tego interes społeczny ze względów ogólnoprewencyjnych, w szczególności w zakresie kształtowania świadomości prawnej społeczeństwa ${ }^{28}$. W interesie społecznym i wymiaru sprawiedliwości nie jest bowiem, aby sędzia indywidualnie składał do sądu prywatny akt

28 S. Szolucha, w: Kodeks postępowania karnego. Komentarz, J. Skorupka (red.), Warszawa 2015, s. 219. 
oskarżenia przeciwko oskarżonemu i narażał się na osobisty z nim kontakt, co mogłoby dopiero wówczas uzasadniać wyłączenie sędziego na podstawie art. $41 \S 1$ k.p.k. z powodu podejrzenia zaistnienia konfliktu między sędzią a oskarżonym, determinowanego osobistą urazą i antypatią, a skutkujących skierowaniem ścigania przez pokrzywdzonego.

To, że pomówienie dokonywane przez oskarżonego nie wyczerpuje znamion przestępstwa z art. 234 k.k. i z art. $212 \S 1$ k.k., nie przesądza a'priori o braku odpowiedzialności oskarżonego za inne jeszcze przestępstwo i nie uzasadnia zawsze przyjęcia, że zachowanie takie mieści się $\mathrm{w}$ granicach prawa do obrony.

Oskarżony może zostać pociągnięty do odpowiedzialności karnej ze względu na sposób realizacji swego prawa do obrony. Niezależnie od zawartości merytorycznej wyjaśnień oskarżonego przybierającej formę pomówienia, gdy forma przybiera postać obelgi czy pogardy dla innej osoby, wówczas do rozważenia pozostaje kwestia wyczerpania przez niego znamion przestępstwa opisanego w dyspozycji art. $216 \S 1$ k.k., a jeżeli ma to miejsce na sali rozpraw podczas składania wyjaśnień - art. $226 \S 1$ k.k. Przez zniewagę rozumie się takie zachowanie, które według zdeterminowanych kulturowo i powszechnie przyjętych ocen stanowi wyraz pogardy dla drugiego człowieka. Czy dana wypowiedź oskarżonego będzie wypełniała dyspozycję art. 216 k.k., zależeć będzie od oceny obiektywnej i niezależnie od obecności na miejscu zdarzenia osoby, której wypowiedź bezpośrednio dotyczy ${ }^{29}$. Przedmiotem ochrony w art. $226 \S 1$ k.k. jest autorytet osób realizujących pełnienie swych obowiązków, działalność instytucji państwowych, a także ich godność. Jest to przestępstwo bezskutkowe, tj. nie wymaga doznania przez adresata poczucia poniżenia. Chroniona godność pojmowana jest w sposób zobiektywizowany, określony przez powszechnie przyjęte normy kulturalno-obyczajowe ${ }^{30}$. Sytuacja procesowa oskarżonego i potrzeba ochrony jego konstytucyjnych praw nigdy nie może godzić we wskazane wartości. Należy też podkreślić, że pojęcie zniewagi musi być interpretowane jednolicie, zarówno na gruncie przepisów art. $226 \S 1$ k.k. oraz art. 135 $\S 2$ k.k., jak i art. 216 k.k. ${ }^{31}$

Wyjaśnienia oskarżonego o charakterze pomawiającym stanowią pełnoprawny dowód w sprawie, który podlega ocenie jak każdy inny dowód w procesie karnym. Wymaga on tylko zachowania większej dozy krytycyzmu i wnikliwości

29 W. Kulesza, Zniestawienie i zniewaga, Warszawa 1984, s. 167-169.

30 Wyrok SA w Białymstoku z 6 grudnia 2012 r., II AKa 218/12, LEX nr 1254312.

31 Wyrok SA w Łodzi z 17 stycznia 2013 r., II AKa 273/12, LEX nr 1294813. 
ze strony organów procesowych. Prymat prawa do obrony oskarżonego uzasadnia przyjęcie, że w razie konfliktu tego prawa $\mathrm{z}$ ochroną dóbr innych osób wyłączona jest możliwość pociągnięcia dodatkowo oskarżonego za treść pomawiających wyjaśnień do odpowiedzialności karnej, jeśli jego zachowanie pozostaje w bezpośrednim związku z prawem do obrony. Przekroczenie tych granic pozbawia oskarżonego ochrony prawnej i uzasadnia rozważenie wszczęcia postępowania o przestępstwo z art. 234 k.k., art. $212 \S 1$ k.k., art. $226 \S 1$ k.k. lub $\mathrm{z}$ art. $216 \S 1$ k.k.

\section{Bibliografia}

\section{Akty prawne}

Konstytucja Rzeczypospolitej Polskiej z dnia 2 kwietnia 1997 r. (Dz.U., nr 78, poz. 483).

Konwencja z dnia 4 listopada 1950 r. o Ochronie Praw Człowieka i Podstawowych Wolności (Dz.U. z 1993 r., nr 61, poz. 284).

\section{Opracowania}

Agacka Joanna, Wyjaśnienia oskarżonego - Pomówienie, AUL 1994/60, s. 119-127.

Błoński Michal, w: Piotr Kruszyński, Michał Błoński, Monika Zbrojewska, Dowody i postępowanie dowodowe $w$ procesie karnym. Komentarz praktyczny z orzecznictwem. Wzory pism procesowych, Warszawa 2015.

Bratoszewski Jerzy, Gardocki Lech, Gostyński Zbigniew, Przyjemski Stanisław M., Stefański Ryszard A., Zabłocki Stanisław, Kodeks postęowania karnego. Komentarz, t. I, Warszawa 1998.

Cieślak Marian, Glosa do uchwaty SN (7) z 29 czerwca 1972 r., VI KZP 67/71, Państwo i Prawo 1973/11, s. 182-186.

Czapigo Anna, Wyjaśnienia oskarżonego jako środek dowodowy w procesie karnym, Wojskowy Przegląd Prawniczy 2001/1, s. 61-78.

Dąb Adolf, Prawo do obrony, Państwo i Prawo 1954/3, s. 444-464.

Daszkiewicz Wiesław, Samooskarżenie a prawo do milczenia, Państwo i Prawo 1974/2, s. 3-20.

Gardocka Teresa, Materialne granice prawa do obrony w procesie karnym, w: Prawo do obrony w postępowaniu penalnym, Warszawa 2014.

Gruza Ewa, Psychologia sąowa dla prawników, Warszawa 2017.

Grzegorczyk Tomasz, Tylman Janusz, Polskie postępowanie karne, Warszawa 2014.

Grześkowiak Alicja, Wiak Krzysztof (red.), Kodeks karny. Komentarz, Warszawa 2017, wyd. 4, Komentarz do art. 234 k.k., Legalis.

Klejnowska Monika, Oskarżony jako osobowe źródło informacji o przestęstwie, Kraków 2004, s. 258 .

Królikowski Michal, Zawłocki Robert (red.), Kodeks karny. Część szczególna. Tom II, Komentarz do art. 222-316, Warszawa 2013, Komentarz do art. 234 k.k., Legalis.

Kruszyński Piotr, Realizacja prawa do obrony na rozprawie głównej, Studia Iuridica 1985/13, s. $95-109$. 
Kucharczyk Mariusz, Glosa do uchwaty SN z 11 stycznia 2006 r., I KZP 49/05, Monitor Prawniczy 2007/14, s. 802-806.

Kulesza Witold, Zniestawienie i zniewaga, Warszawa 1984.

Kunicka-Michalska Barbara, Prawo oskarżonego do obrony, a fatszywe oskarżenie, Palestra 1968/6, s. 41-49.

Kunicka-Michalska Barbara, w: Kodeks karny. Część szczególna. Komentarz, t. II, Andrzej Wąsek (red.), Warszawa 2004.

Leśniak Marek, Wybrane problemy badań psychologicznych $w$ procesie karnym, Prokuratura i Prawo 1998/5, s. 65-80.

Lipczyńska Maria, Stanowisko oskarżonego w procesie karnym Polski Ludowej, Warszawa 1956.

Lyczywek Roman, Prawo oskarżonego do wypowiadania się $w$ procesie, Państwo i Prawo 1970/2, s. 297-310.

Marek Andrzej, Kodeks karny. Komentarz, Warszawa 2005.

Nelken Jan, Glosa uchwaty SN (7) z 29 czerwca 1972 r., VI KZP 67/71, Nowe Prawo 1973/7-8, s. $1198-1203$.

Nelken Jan, Wyjaśnienia oskarżonego na tle kodeksu postępowania karnego, Palestra 1971/5, s. 66-78.

Papierkowski Zdzisław, Granice obrony oskarżonego w procesie karnym, Głos Prawa 1935/9-10, s. $542-551$.

Pawelec Kazimierz J., Wyjaśnienia podejrzanego, zeznania świadka i instytucja świadka koronnego. Komentarz, Warszawa 2003.

Razowski Tomasz, w: Kodeks karny. Część szczególna. Komentarz, Jacek Giezek (red.), Warszawa 2014.

Sobolewski Zbigniew, Samooskarżenie w świetle prawa karnego, Warszawa 1982.

Stefański Ryszard A., Zawiadomienie o niepopetnionym przestepstwie w świetle prawa karnego, Prokuratura i Prawo 2005/10, s. 31-43.

Szewczyk Maria, w: Kodeks karny. Część szczególna, t. II, Andrzej Zoll (red.), Warszawa 2013.

Szołucha Sławomir, w: Kodeks postępowania karnego. Komentarz, Jerzy Skorupka (red.), Warszawa 2015.

Śliwiński Stanisław, Polski proces karny przed sądem powszechnym. Zasady ogólne, Warszawa 1948.

Wiliński Pawel, Glosa do uchwały SN z 11 stycznia 2006 r. I KZP 49/05, Orzecznictwo Sądów Polskich 2007/5, s. 55-56.

Wojciechowski Bartosz W., Analiza i ocena zeznań świadków, Sopot 2016.

Wojciechowski Janusz, Kodeks karny. Komentarz. Orzecznictwo, Warszawa 1998.

Zając Bogusław, Przyznanie się oskarżonego do winy w procesie karnym, Kraków 1995.

Zoll Andrzej, w: Kodeks karny. Część ogólna, Włodzimierz Wróbel, Andrzej Zoll (red.), Warszawa 2016

Zoll Andrzej, Okoliczności wyłączające bezprawność czynu. Zagadnienia ogólne, Warszawa 1982.

\section{Orzecznictwo}

Postanowienie SN z 5 maja 2006 r., V KK 387/05, LEX nr 186970.

Postanowienie SN z 25 kwietnia 1995 r., II KO 6/95, Prok. I Pr. 1995/7-8, poz. 7.

Uchwała SN (7) z 29 czerwca 1972 r., VI KZP 67/71, OSNKW 1972/10, poz. 150. 
Uchwała SN z 11 stycznia 2006 r., I KZP 49/05, OSNKW 2006/2, poz. 12.

Uchwała SN z 18 lutego 1961 r., VI KO 29/59, ospika 1961/7-8, s. 462-464.

Wyrok SN z 22 października 2013 r., V KK 233/13, OSNKW 2014/3, poz. 21.

Wyrok SN z 14 września 2004 r., IV KK 129/04, LEX nr 137755.

Wyrok SN z 9 lutego 2004 r., V KK 194/03, OSNKW 2004/4, poz. 42.

Wyrok SN z 15 lutego 1985 r., IV KR 25/85, OSNKW 1985/11-12, poz. 103.

Wyrok SN z 11 września 1984 r., IV KR 141/84, OSNPG 1985/6, poz. 85.

Wyrok SN z 9 kwietnia 1974 r., III KR 32/74, Biul. SN 1974/9-10, poz. 228.

Wyrok SN z 15 września 1970 r., V KRN 311/70, NP 1971/3, s. 404.

Wyrok SA w Lublinie z 16 stycznia 2014 r., II aka 261/13, KZS 2014/5, poz. 75.

Wyrok SA w Łodzi z 17 stycznia 2013 r., II aka 273/12, LEX nr 1294813.

Wyrok SA w Białymstoku z 6 grudnia 2012 r., II aka 218/12, LEX nr 1254312

\section{Michał BŁOŃSKI}

\section{RESPONSIBILITY OF THE ACCUSED OF SLANDER AGAINST THE RIGHTS OF DEFENCE}

\section{( Summary)}

This paper deals with important theoretical and practical issues connected to explanations of the accused containing the features of slander. The study presents the types of slander, but primarily focuses on whether and when the accused is held liable for the slander of another person in the context of explanations. It has been emphasized that the lack of criminal responsibility of the accused for the content of such explanations is applicable only when the accused acts in defence and not "on the occasion" of defence. Determining whether the accused is held liable for the content of the slander, depending on whether it acts within the rights of the defence or whether it exceeds these limits, must always be considered against the background of the case. The rights of defence in the analyzed aspect - and the understanding of the term "within the limits of the right of defence" - should be interpreted extensively, as this right cannot be abused by the accused.

Keywords: hearing; evidence; rights of defence; explanation of the accused; slander against 